\title{
A védőnői méhnyakszúrési pilot program értékelése
}

\author{
Vajda Réka ${ }^{1}$ - Árváné Egri Csilla ${ }^{2}$ - Kovács Attila dr. ${ }^{2}$ \\ Budai András dr. ${ }^{2}$ - Döbrőssy Lajos dr. ${ }^{2}$. Koiss Róbert dr. ${ }^{3}$ \\ Kívés Zsuzsanna ${ }^{1}$. Boncz Imre dr. ${ }^{1}$
}

${ }^{1}$ Pécsi Tudományegyetem, Egészségtudományi Kar, Egészségbiztosítási Intézet, Pécs ${ }^{2}$ Országos Tisztifőorvosi Hivatal, Budapest

${ }^{3}$ Egyesített Szent István és Szent László Kórház-Rendelőintézet, Szülészeti-Nőgyógyászati Osztály, Budapest

\begin{abstract}
Bevezetés: Az Európai Unió által támogatott TÁMOP-6.1.3.A-13/1-2013-0001 program keretében a védőnóket szándékoztunk bevonni a szervezett méhnyakszúrési programba. Célkitüzés: A felmérés elkészítésének célja értékelni a méhnyakszürési képzésre jelentkező védőnők elégedettségét a felkészítés oktatóit és oktatási segédanyagait illetően, továbbá megállapítani, hogy a kapott ismeretek mennyiben feleltek meg elvárásaiknak. Módszer: A védőnók elégedettségét kérdőíves felméréssel, négy kérdéscsoport mentén vizsgáltuk: oktatók, oktatási segédanyag, a továbbképzési nap értékelése, a képzés során kapott ismeretek megfelelősége. A kérdőívek kitöltésének időszaka: 2014. október-december. Az összesített adatok értékelése leíró statisztikai módszerrel történt. Eredmények: 2148 védőnő adatait értékeltük, akik 5-ös skálán a szülész-nőgyógyász szakemberek teljesítményét összességében 4,65, a védőnőkét 4,61, a népegészségügyi-szúrési szakemberekét 4,56, az informatikai szakemberekét pedig 4,52 pontra értékelték. A képzés során átadott oktatási segédanyag minősége $98 \%$-uk számára hasznosítható volt, a kapott ismeretek elvárásaiknak megfelelőek voltak. Következtetés: A védőnők elégedettek voltak a pilot program keretében végzett elméleti felkészítő oktatással. A szakmailag jól felkészült védőnők hozzájárulhatnak a méhnyakszűrési program sikeréhez. Orv. Hetil., 2017, 158(12), 461-467.
\end{abstract}

Kulcsszavak: méhnyakrák, méhnyakszưrés, humán papillomavírus, védőnő

\section{Assessment of the pilot program for cervical cancer screening by health visitors}

Introduction: Within the tender (6.1.3.A-13/1-2013-0001) supported by the European Union, we wished to involve health visitors into the organized cervical cancer screening program. Aim: The aim of our survey was to assess the satisfaction of health visitors, instructors, and that of the teaching aids. Furthermore, we wished to assess whether the teaching materials met the expectations. Method: Satisfaction of the health visitors was assessed by a survey, in four groups of questions. These involved the assessment of the instructors, the teaching aids, evaluation of the further training day, and the compliance with the knowledge of training. Period for completion of the questionnaires lasted from October to December in 2014. We used descriptive statistics for data evaluation. Results: Data of 2148 health visitors was evaluated. They rated the performance of gynecologist-obstetricians 4.65 , that of health visitors 4.61 , that of public health professionals 4.56 , and that of IT specialists $4.52 .98 \%$ of the teaching aids were useful for them and the acquired knowledge was appropriate with their expectations. Conclusion: The health visitors were satisfied with the theoretical instruction within the pilot program. The professionally well prepared health visitors may contribute to the success of the cervical cancer screening program.

Keywords: cervical cancer, cervical cancer screening, human papillomavirus, health visitors

Vajda, R., Á. Egri, Cs., Kovács, A., Budai, A., Döbrössy, L., Koiss, R., Kivés, Zs., Boncz, I. [Assessment of the pilot program for cervical cancer screening by health visitors]. Orv. Hetil, 2017, 158(12),461-467.

(Beérkezett: 2016. szeptember 12.; elfogadva: 2016. november 10.) 


\section{Rövidítések}

EMMI = Emberi Erőforrások Minisztériuma; ESzCsM = Egészségügyi, Szociális és Családügyi Minisztérium; HPV = humán papillomavírus; Liliom II. = Liliom Program II. üteme; NHS = National Health Service; OTH = Országos Tisztifóorvosi Hivatal; TÁMOP = Társadalmi Megújulás Operatív Program; VMMP I. = Védőnői Méhnyakszúrő Mintaprogram I.; VMP II. = Védőnői Méhnyakszürő Program II.; VMP III. = Védőnői Méhnyakszűrő Program III.

A méhnyakrák napjainkban a világ nagy részén jelentős népegészségügyi probléma, 2012-ben több mint 500 ezer új esetet fedeztek fel és több mint negyedmillió nő vesztette életét a betegség miatt. Hazánkban a halálozási trend 2002-ig meghaladta az évi 500 esetszámot, az ezt követő csökkenés egyértelműen a méhnyakszűrés bevezetésének volt köszönhető [1]. Az Egészségügyi Minisztérium a „cervixprogramot” 1981-ben indította el, amelynek célja a 20-65 év közötti nők kétévenkénti, szakorvos által végzett citológiai méhnyakszűrő vizsgálata volt $[2,3]$. Az Országgyưlés 46/2003. (IV. 16.) számú határozatában elfogadta a szervezett méhnyakszürés bevezetéséről szóló stratégiai programot, amelynek eredményeként elindult az egész női lakosságot érintô szûrési program. A program célja volt, hogy a háromévenkénti meghívás eredményeként 2010-ig a felére csökkenjen azoknak a 25-65 év közötti nőknek a méhnyakrák miatti halálozása, akik eddig nem részesültek szürésben [4-6]. A szervezett szürési program egészséggazdasági számítások alapján költséghatékonynak bizonyult és társadalombiztosítási támogatásban részesült [7, 8]. A 2005-ben meghirdetett Liliom Program eredményeként a részvétel a korábbi 4\%-ról 8\%-ra nőtt [9]. Nyugat-európai modellek mintáján elindult a védőnők felkészítése, bevonása a szürésbe [10]. A Liliom Program második ütemében (Liliom II.) kísérleti jelleggel indult el a védőnői mintaprogram, amelynek eredményeként $10 \%$-ra nőtt a résztvevők aránya, a mortalitás pedig 15\%-kal csökkent [11]. 2005 és 2008 között 50000 nő vett részt a szûrővizsgálaton, a megjelenők közel fele még sosem vagy öt évnél régebben volt utoljára szürésen [12]. A Védőnői Méhnyakszűrő Mintaprogram (VMMP I.) 2008-ban indult útjára. A program megkezdése előtt 110 önként jelentkező védőnő vett részt elméleti és gyakorlati képzésben. A területi védőnőkhöz 2009 márciusa és májusa között 30717 nő kapott meghívót. Az érintettek közül 13823 nőt sikerült elérni, közülük 34\% (4764 fö) vett részt szürésen. A mintaprogram 2010-ben Védőnői Méhnyakszűrő Program (VMP II.) néven folytatódott, amelyben 349 településen 213 védőnő végzett méhnyakszürést. A program során 45899 olyan nő kapott meghívólevelet, akik utoljára három évnél régebben vettek részt szürésen. A kezdeményezés eredményeként a korábbi 2,45-6,57\%-ról 24,14\%-ra emelkedett a szúrésen megjelenő nők aránya [13]. A Védőnői Méhnyakszürő Program III. (VMP III.) 2011-ben indult, amelynek keretében 300 településen 181 védőnő végzett szűrési tevékenységet. A három év alatt országosan a meghívott 101874 nő $50 \%$-a volt elérhető a védőnők által, és közülük 15425 nő (30\%) vett részt a szűrésen. A programok eredményei alapján a védőnők alkalmasak és képesek a kenetvétel elvégzésének megtanulására és kivitelezésére, a lakónépesség megszólítására [14]. A területi védőnői ellátásról szóló 49/2004. (V. 21.) ESzCsM rendelet $3 . \$ c$ ) pontja szerint a védőnők korábbi nővédelmi feladatai közé tartozik a lakossági célzott szûrővizsgálatok szervezésében való részvétel, amelyet a 28/2013. (IV. 5.) EMMI rendelet alapján a „népegészségügyi célú méhnyakszürés végzése" feladatkörrel egészítettek ki. A rendelet meghatározta, hogy azok a védőnők jogosultak a feladat ellátására, akik az OTH vagy orvos- és egészségtudományi képzéssel rendelkező intézmény által tartott, minimum 40 órás továbbképzésen vagy egészségügyi szakirányú szakmai továbbképzésen részt vesznek [15-17].

Ennek eleget téve indult el a TÁMOP-6.1.3.A-13/ 1-2013-0001 azonosítójelû program, amely a védőnői méhnyakszürés végzésére való előkészületet kívánta támogatni azáltal, hogy felkészíti a védőnőket a méhnyakrák megelőzésében való aktívabb szerepvállalásra.

Elemzésünk célja a képzésre jelentkező védőnők egynapos frontális elméleti képzéssel való elégedettségének, a felkészítés oktatóinak, valamint az oktatási segédanyagoknak az értékelése, továbbá annak megállapítása, hogy a képzés során kapott ismeretek és a továbbképzés szervezése mennyiben feleltek meg a szakemberek elvárásainak.

\section{Módszer}

\section{A védônôi pilot program bemutatása}

A védőnői pilot szűrési program a TÁMOP-6.1.3.A-13/ 1-2013-0001 azonosítójelü „Pilot jellegü szüróprogramok (védönői méhnyakszürési, illetve vastagbélszürési programok) kiterjesztésének támogatása" címú pályázat keretében valósult meg. A projekt közvetlen célkitüzése, hogy a védőnők hatékonyan részt vegyenek a körzetükben szervezett méhnyakszúrés szervezésében, valamint bekapcsolódva a szervezett méhnyakszürés folyamatába, alkalmasak legyenek önállóan méhnyakszűrést végezni, javítva a körzetükben lakó célcsoport tagjai számára a szúrés elérhetőségét, hosszú távon pedig a tervezett tevékenység járuljon hozzá a méhnyakrákból eredő halálozás kedvezőtlen folyamatának megállításához.

A képzés, továbbképzés három választható módon valósult meg attól függően, hogy a jelentkező védőnő részt vett-e már korábban a Védőnői Méhnyakszürő Programok képzésén vagy sem. A korábban már képzett védőnők egynapos továbbképzésen vehettek részt, az újonnan jelentkező védőnők pedig két továbbképzési mód közül választhattak: 1. elméleti képzésen való részvétel, 2. elméleti és gyakorlati - kenetvételi - képzésen való részvétel. A projekt tehát lehetőséget biztosított a védő- 
nők számára csak elméleti képzésen való részvételre, amellyel a későbbiekben hatékonyan részt tudnak venni a szưrésen való részvétel fontosságának hangsúlyozásában, a szürésre jogosultak szakszerú és részletes tájékoztatásában, azonban ez a továbbképzés ôket a kenetvétel végzésére nem jogosítja. Azok a védőnók, akik mind az elméleti és gyakorlati továbbképzésen is részt vesznek, végezhetnek majd méhnyakszűrési tevékenységet körzetükben. Az elméleti továbbképzés megyei vagy járási szinten szerveződött, a méhnyakrákkal és megelőzésével, a szervezett szúrésekkel, védőnői módszertannal és a szürésekkel kapcsolatos kommunikációs, illetve elektronikus adatszolgáltatás ismereteinek elsajátításával foglalkozott.

Az elméleti képzést sikeresen teljesítőknek a gyakorlati oktatást megyénként kiválasztott nőgyógyászok tartották a nőgyógyászati szakellátó rendelóikben. A cél a méhnyakszürés technikájának és a szưréshez kapcsolódó tevékenységnek az elsajátítása, jártasság megszerzése volt. A gyakorlati képzés teljesítésének feltétele legalább 30 kenet sikeres levétele volt.

Az egynapos továbbképzésen részt vett, korábban már képzett (VMP-s) védőnők, valamint az elméleti és gyakorlati képzésen részt vett, kiképzett „új védőnők” a projekt idejében méhnyakszűrési tevékenységet végezhetnek körzetükben. A projekt megvalósítása alatt megközelítőleg 75 ezer (25-65 év közötti) nő szűrése valósulhat meg.

1. táblázat |A képzésben részt vevő védőnők térségek szerinti megoszlása

\begin{tabular}{lc}
\hline Térség & $\begin{array}{c}\text { Védőnoók száma } \\
\text { (fó) }\end{array}$ \\
\hline Budapest & 260 \\
Bács-Kiskun megye & 90 \\
Baranya megye & 59 \\
Békés megye & 140 \\
Borsod-Abaúj-Zemplén megye & 275 \\
Csongrád megye & 71 \\
Fejér megye & 48 \\
Győr-Moson-Sopron megye & 84 \\
Hajdú-Bihar megye & 132 \\
Heves megye & 90 \\
Jász-Nagykun-Szolnok megye & 50 \\
Komárom-Esztergom megye & 65 \\
Pest megye & 202 \\
Somogy megye & 108 \\
Szabolcs-Szatmár-Bereg megye & 149 \\
Tolna megye & 54 \\
Vas megye & 75 \\
Veszprém megye & 102 \\
Zala megye & 94 \\
\hline Osszesen & 2148 \\
\hline
\end{tabular}

\section{Vizsgálati módszertan}

Az OTH által szervezett továbbképzéseken a képzés szakmai részének oktatását helyszínenként négy - népegészségügyi-szűrési, szülész-nőgyógyász, védőnő, informatikai - szakember végezte. A kiosztott kérdőívek a részt vevő védőnők továbblépzéssel kapcsolatos elégedettségéról szóltak. A kérdések négy témakört érintettek: oktatók értékelése, oktatási segédanyag értékelése, a képzés során kapott ismeretek megfelelősége, továbbképzési nap értékelése. A kérdőívben szereplő kérdések zárt egyválaszos kérdések, nyitott kérdések, és zömmel 1-tôl 5-ig terjedő skálán megválaszolandó kérdések voltak. A képzés és így a kérdőívek kitöltésének időszaka: 2014. október-december. Az összesített adatok értékelése leíró statisztikai módszerrel történt.

A felmérés egyedülálló, hiszen a védőnők áldozatos munkájának eredménye - szűrésen való részvételi arány növekedése - a korábbi mintaprogramok nőlakosságot érintő eredményeinek értékelésekor megtörtént, azonban az elméleti képzést teljesítő védőnők elégedettségének mérésére, annak értékelésére ilyen formában ez idáig nem került sor.

\section{Eredmények}

Az értékelőlapokat 2148 védőnő töltötte ki. A kitöltött kérdőívek alapján a válaszadók életkora, valamint munkaeró-piaci státusza állapítható meg. Az 1927 értékelhető válasz alapján elmondható, hogy a védőnők többsége (90\%) a 25-54 éves korcsoporthoz tartozik, 8,5\%-uk 55-64 éves, 1,5\%-uk 15-24 éves. Munkaerö-piaci státusz szerint a válaszadó 2134 fó $98 \%$-a jelenleg rendelkezik állással - közülük 30 fő vállalkozó -, 2\%-uk inaktív, és mindössze négy fó munkanélküli. A képzésben részt vevő védőnők térségek szerinti megoszlását az 1 . táblázat foglalja össze.

\section{Az oktatók munkájának értékelése}

A népegészségügyi-szürési szakemberek munkáját 5-ös skálán összességében átlagosan 4,56 pontra értékelték a védőnók. Kiemelkedően elégedettek voltak a szakmai felkészültségükkel, rugalmasságukkal és a csoport együttmúköodésének irányításával. Az előadói, prezentációs képességüket 4,48 pontra értékelték, a figyelmük felkeltésének eredményességét pedig 4,44 pontra.

A szülész-nőgyógyász szakemberek munkáját átlagosan 4,65 pontra értékelték a képzésben részt vevő védőnők. Szakmai felkészültségüket kimagaslónak minősítették, rugalmasságukat és a csoport együttmúködésének irányításával kapcsolatos eredményességüket is magas szintűnek tartották. A szakemberek előadói, prezentációs képességét, valamint a figyelem felkeltésének, fenntartásának eredményességét valamelyest alacsonyabbnak, de így is kiemelkedőnek vélték a résztvevók. 
A védőnő szakemberek munkáját összességében átlagosan 4,61 pontra értékelték, akik ezáltal a szakmai rész oktatói közül a második legmagasabb összesített pontszámot kapták a szülész-nógyógyász szakembereket követve. Szakmai felkészültségüket 4,79, rugalmasságukat 4,61 pontra értékelték. Előadói, prezentációs képességükre átlagosan 4,58 pontot kaptak, a csoport együttmúködésének irányításáért 4,56-ot, a figyelmük felkeltésének eredményességéért pedig 4,51-ot.

$\mathrm{Az}$ informatikai szakemberek munkáját átlagosan 4,52 pontra értékelték a képzés résztvevői. Szakmai felkészültségüket 4,67 pontra, rugalmasságukat 4,57, a csoport együttmúködésének irányításával kapcsolatos eredményességüket 4,48 pontra értékelték átlagosan. A szakemberek előadói, prezentációs képességére, valamint a figyelem felkeltésére, fenntartására 4,44 pontot adtak.

Összesítve a négy szakember értékelését az egyes kérdések szerint, elmondható, hogy a képzésben részt vevő védőnők minden szempontból leginkább a szülész-nőgyógyász szakemberekkel, azt követően a védőnőkkel, majd a népegészségügyi-szűrési szakemberekkel és végül az informatikai szakemberekkel voltak elégedettek (1. ábra).

\section{Az oktatási segédanyag értékelése}

A képzés során átadott oktatási segédanyag minősége a résztvevők 98\%-a számára hasznosítható volt, 2\% számára nem. A védőnőknek volt lehetőségük szövegesen is leírni véleményüket a kiadott anyagokkal kapcsolatban. Mindössze 130 fó válaszolt a kérdésre, többségük negatív megjegyzéseit írta le, miszerint a kiadott anyagok nem követték az előadások sorrendjét, illetve a táblázatok, ábrák az apró betûk, valamint a nyomtatási kép miatt több helyen nehezen olvashatóak voltak.

\section{A képzés során kapott ismeretek megfelelösége}

A képzés során kapott ismeretek a védőnők elvárásainak megfelelőek voltak. Többségük $(78,6 \%)$ erre számított, 13\%-uk szerint jobb, mint amire számított, míg mindössze $8,4 \%$ véleménye szerint volt gyengébb a képzés annál, mint amit előzetesen várt (2. ábra).

\section{A továbbképzési nap értékelése}

A részt vevő védőnők válaszaik alapján az étkezés minőségével és mennyiségével kimagasló mértékben elégedettek voltak. A rendezvényszervezést is jónak értékelték, azonban a rendezvényterem felszereltségével már kevésbé voltak megelégedve, nem beszélve a terem komfortjáról, amit a legalacsonyabb szintű́nek véltek az értékelési szempontok közül (3. ábra).

A kérdőívkitöltés során a védőnők megnevezhettek három-három dolgot, ami tetszett, illetve ami nem tetszett nekik a képzéssel kapcsolatban. Tetszésüket legin-



1. ábra | A szakemberek munkájának összesített értékelése

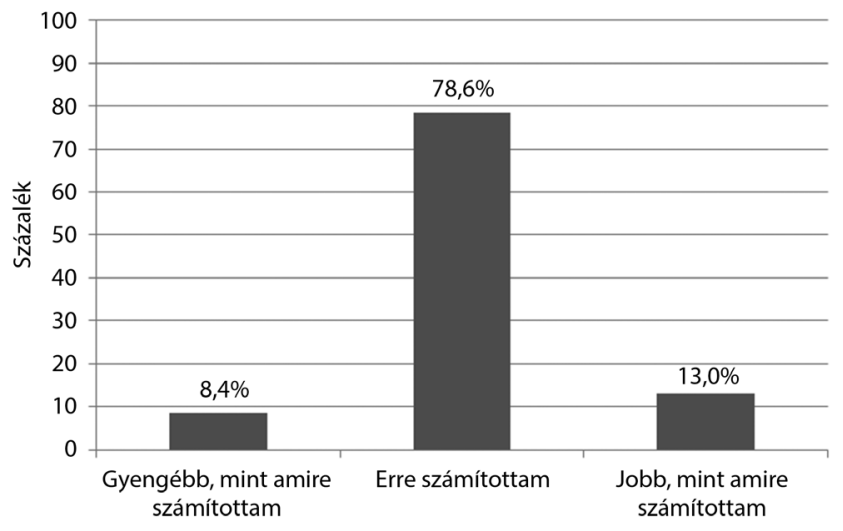

2. ábra $\mid$ A képzés során kapott ismeretekkel való elégedettség

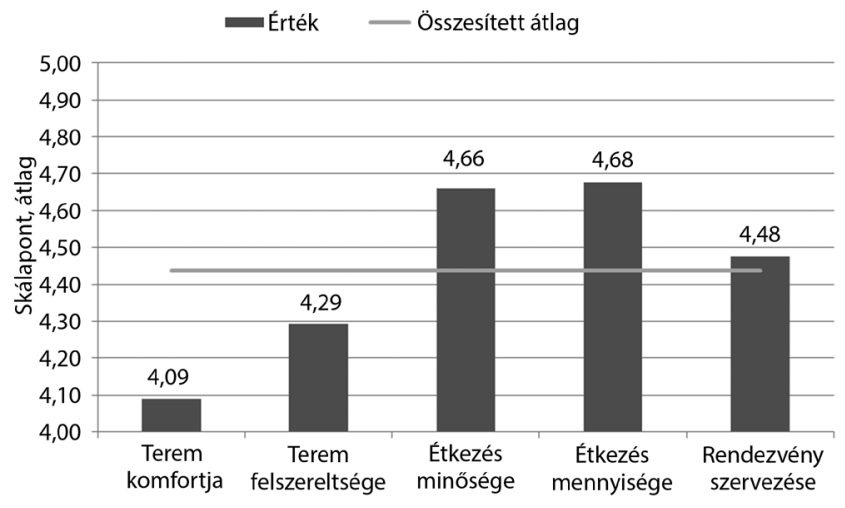

3. ábra $\mid$ A továbbképzési nap értékelése

kább az oktatók felkészültsége, az előadások menetének jól felépített volta, követhetősége, az oktatók rugalmassága, a tananyagok kiadásának lehetősége, és a számukra biztosított ellátás nyerte el.

Kevéssé elégedettek a kiadott anyagok olvashatóságával, a terem komfortosságával (székek, szellőztetés, helyszúke, asztalhiány), technikai felszereltségével (vetített dia láthatósága, mikrofon) és a helyszín megközelíthetőségével voltak.

Összességében megállapítható, hogy a részt vevő védőnők a továbbképzésen leginkább az oktatókkal voltak elégedettek, majd azt követően a helyszínnel, étkezéssel, 


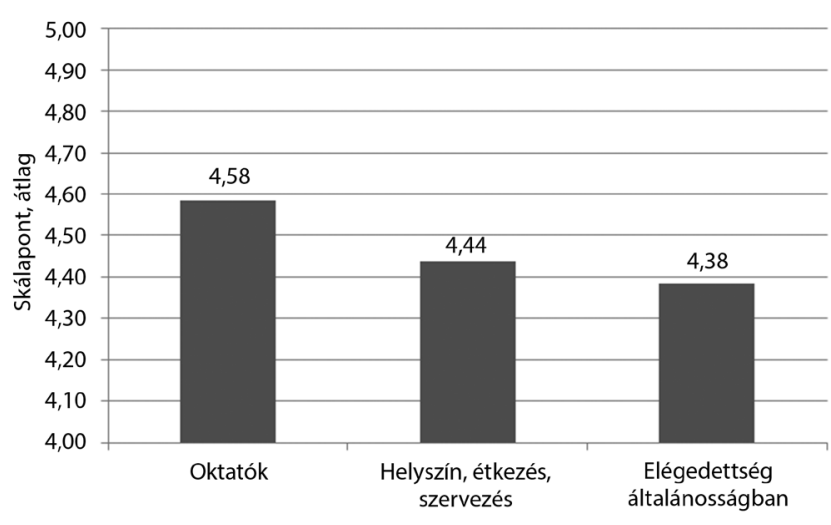

4. ábra $\mid$ A továbbképzéssel való elégedettség az oktatókat, a helyszínt, étkezést, szervezést, valamint általánosságban értékelve

szervezéssel együttesen. A kérdő́ívben szereplő utolsó, skálán értékelendő kérdés a továbbképzéssel való elégedettség mindent egybevetve, amely szerint 4,38 -os átlagpontszámot adva a védőnők jónak értékelték a továbbképzést (4. ábra).

\section{Megbeszélés}

A védőnők általi értékelés elemzését tekintve megállapíthatjuk, hogy a szakemberek kiemelkedően elégedettek voltak a továbbképzés oktatóival, szakmai felkészültségükkel, a kapott oktatási segédanyagokkal és az így elsajátítható ismeretekkel. Többségük elvárásainak megfelelt a továbbképzés vagy meg is haladta azokat. A védőnők értékelték az előadó szakemberek áldozatos munkáját, amellyel igyekeztek hozzájárulni a képzés sikerességéhez, a védőnők érdeklődésének fenntartásához, ezzel azt célozva, hogy a részvevőḱk körzeti munkájuk során nagyobb hatékonysággal legyenek képesek ösztönző, támogató segítséget nyújtani a szúréstőll távol maradó, bátorításra szoruló nők részére.

A program szervezői szemszögéből teljesül a védőnői compliance, a védőnő́k jelentkezésükkel biztosították elhivatottságukat szakmájuk iránt, ami az egyik - ha nem legfontosabb - sarokköve az újonnan bevezetni tervezett módozatnak, amellyel a szakorvosi szűrést kívánják kiterjeszteni a védőnói körzetekre a szakképzett, gyakorlati tevékenység elvégzésére felkészített szakemberek tevékenységén keresztül. A program sikeresnek ítélhető, hiszen a képzésre jelentkező védőnők a továbbképzések teljesítése révén jelentôs segítséget nyújthatnak a megelőzés terén. Felkészültségükkel, ösztönzésükkel elérhetik a szưrésen megjelenő nők részarányának növekedését, ezen keresztül a pozitív esetek kiszűrésének lehetőségét, következményesen kezelésük időben való megkezdése által a halálozás csökkenését.

A szakdolgozói méhnyakszűrési tevékenység nemzetközi szinten igen elterjedt, ezek alapján került bevezetésre hazánkban is. Célja az, hogy az alapellátáshoz közelebb kerüljön a szúrés elvégzése, hiszen a citológiai vizsgálat bizonyítottan hatékony módszere a méhnyak- rák megelőzésének, ami rendelkezésünkre áll, csak élni kell a lehetőséggel $[18,19]$. A szakorvosok mellett ápolók és szülésznők végzik a kenetvételt Finnországban és Görögországban, szülésznők Lengyelországban, Észtországban, Svédországban és Spanyolországban. Írországban, az Egyesült Királyságban és Hollandiában pedig képzett asszisztensek vesznek részt a szưrớtevékenységben $[20,21]$.

Finnországban a program hatására jelentős mértékben csökkent a méhnyakrák előfordulási gyakorisága és halálozási aránya. 2015-ös adatok szerint a szürési lefedettség - ami a nők ajánlott intervallumon belüli szürését jelző mutató - $66,8 \%$ volt $[22,23]$. Svédországban az 1960-as évek óta folyik egyes régiókban szervezett szürővizsgálat, a lefedettség 79,7\% [24, 25]. Az Egyesült Királyság Nemzeti Egészségügyi Szolgálatának (National Health Service - NHS) 1988-ban megkezdett szervezett programjában a kenetek körülbelül $80 \%$-át ápolók veszik le, az öt éven belüli átszürtség már a kilencvenes években meghaladta a 80\%-ot [26]. Észtországban 2006-ban indult szervezett program, a keneteket szülésznők veszik, a részvételi arány 2009-ben elérte a $24,4 \%$-ot $[21,27]$. Írországban a nemzeti populációalapú méhnyakszürést 2008 őszén vezették be, a szúrési lefedettség 74,7\% volt 2015-ben [28]. Hollandiában 1996-ban jött létre egy nemzeti, szervezett szürési program, a kenetvételt egyre gyakrabban képzett asszisztensek végzik, 2003-ban meghívó hatására a nők 65\%-a jelent meg vizsgálaton [21, 29]. Görögországban 2011-ben indult a Nemzeti Méhnyakszúró Program, amelyben szülésznő, ápoló is végezheti a kenetvételt, szerepük a nők részvételének támogatásában jelentős $[21,30]$. Spanyolországban 14 régióban zajlik uniós irányelvekhez közelítő méhnyakszúrés, a keneteket nőgyógyász mellett szülésznő veszi le [2l, 31]. Lengyelországban 2007-ben indult populációalapú szúrés a szülésznő́k bevonásával, 2010-re 5,7\%-kal csökkent a méhnyakrák előfordulása, 3,4\%-kal a halálozás, és a szürési lefedettség 24\%-ra növekedett 2012-re [32].

A népességalapú szürési tevékenység biztosítja, hogy azokat a nőket is elérje a szúrés, akiknek vélhetően a legnagyobb szükségük van a szekunder prevencióra. A szervezett, személyes meghíváson alapuló szürőprogram kezdeti eredményei kedvezőtlen képet mutattak, a hároméves lefedettség 2003 és 2005 között 52,6\% volt a szûrési célpopulációban. Az átszưrrtségi adatok javítása összetett, megoldandó probléma, amelynek egyik kiemelt területe a nők ismereti szintjének növelése [3336].

A védőnők bevonása a méhnyakszưrésbe nemcsak a nemzetközi példák követésére való törekvést jelenti, hanem lehetővé teszi a kistelepüléseken élő nők részvételének fokozását [37]. A 2000-es évek elején az apró falvak lakóit az országos átlagnál 11\%-kal magasabb arányban érintették a daganatos megbetegedések, ami jórészt abból adódik, hogy az egészségügyi szakellátás, a szűrootevékenység távol esik a lakóhelyüktől [38]. Már a 2009-es 
Védőnői Méhnyakszürő Mintaprogramot is sikeresnek ítélték a szakemberek, hiszen éppen az egészségügy számára nehezen hozzáférhető területeken élő nőket érték el és tudták bevonni az ellátásba [39]. A szưrésen részt vevő, probléma esetén jó eséllyel megmenthető nők számának növelését a szû́résben fellelhető egyenlőtlenségek rendezése, képzett szakemberek bevonása, valamint a társszakmákkal való együttmúködés teheti lehetővé [40, 41]. Jelen vizsgálatunknak nem célja a HPV szerepének értékelése a méhnyakrák kialakulásában, azonban a szürés mellett nem elhanyagolható a későbbiekben a védőoltás felvételének fokozása a nők körében, hiszen a fertőzés nem negatív citológiai eredménnyel szoros öszszefüggést mutat a daganat kialakulásával. A humánpapillomavírus-fertőzés elterjedésével, a védőoltás szerepével, valamint annak jellemzőivel, költséghatékonyságával, felvételi szokásaival kapcsolatban több tanulmány is készült az elmúlt évtizedekben [42-48].

\section{Következtetés}

A probléma megoldása igencsak sürgető, hiszen évente még mindig több száz nő veszti életét méhnyakrák miatt, és ennek csökkenése csak akkor várható, ha minden veszélyeztetettnek minősülő nő jogosult és hajlandó lesz szakmailag indokolt időközönként részt venni a szervezett szürővizsgálaton.

Anyagi támogatás: A közlemény a „TÁMOP6.1.3A-13/1-2013-0001 Pilot jellegű szűrőprogramok (védőnői méhnyakszűrési, illetve vastagbélszürési programok) kiterjesztésének támogatása" pályázat keretében készült.

Szerzői munkamegosztás: V. R., Á. E. Cs., K. A., B. A., D. L., K. R., K. Zs., B. I:. A vizsgálat tervezése és lefolytatása. V. R., Á. E. Cs., K. Zs., B. I. : Statisztikai elemzések. K. A., B. A., D. L., K. R.: Irodalomkutatás. V. R., Á. E. Cs., K. Zs., B. I.: A kézirat megszövegezése. A cikk végleges változatát valamennyi szerző elolvasta és jóváhagyta.

Érdekeltségek: A szerzőknek nincsenek érdekeltségeik.

\section{Irodalom}

[1] Ferlay, J., Soerjomataram, I., Dikshit, R., et al.: Cancer incidence and mortality worldwide: sources, methods and major patterns in GLOBOCAN 2012. Int. J. Cancer, 2015, 136(5), E359E386.

[2] Bodó, M., Döbrössy, L.: Results and prospects of cytology-based cervix program. [A citológiai vizsgálatra alapozott cervix-program eredményei és kilátásai.] Orvostudomány, 1982, 33, 391394. [Hungarian]

[3] Bodó, M., Cseh, I., Bösze, P.: Alarm in the cervix program: questions and challenges. [Alarm-helyzet a cervixprogramban: kérdések és feladatok.] Magy. Nőorv. Lapja, 1991, 54(6), 373-375. [Hungarian]
[4] Working Group of Cervical Cancer screening of National Chief Medical Officer' Office: Mass screening of the uterine cervix in the program of the "Decade of Health": perspectives of gynecologic cancer screening in Hungary. [Országos Tisztiföorvosi Hivatal Méhnyakszürési Munkacsoport: Lakossági méhnyakszürés az „Egészség Évtizede” program keretében: törekvések a nőgyógyászati rákszűrés korszerűsítésére Magyarországon.] Orv. Hetil., 2004, 145(1), 35-40. [Hungarian]

[5] Boncz, I., Sebestyén, A., Ember, I.: Organized, nationwide cervical cancer screening programme in Hungary. Gynecol. Oncol., 2007, 106(1), 272-273.

[6] Boncz, I.: Prevention of cervical cancer in low-resource settings. JAMA, 2006, 295(11), 1248.

[7] Boncz, I., Sebestyén, A., Pál, M., et al.: Health economics analysis of cervical cancer screening. [A méhnyakrákszürések egészséggazdaságtani elemzése.] Orv. Hetil., 2003, 144(15), 713-717. [Hungarian]

[8] Endrei, D., Molics, B., Ágoston, I.: Multicriteria decision analysis in the reimbursement of new medical technologies: real-world experiences from Hungary. Value Health, 2014, 17(4), 487489.

[9] National Audit Office: Report on utilization of financial resources expended for oncological screening programmes - [Állami Számvevőszék: Jelentés az egyes onkológiai szürési programokra fordított pénzeszközök hasznosulásának ellenőrzéséről - 2008.] Available from: https://www.asz.hu/storage/files/files/\%C3\% 96sszes\%20jelent\%C3\%A9s /2008/0805j000.pdf?ctid=749 [accessed: October 25, 2016]. [Hungarian]

[10] Institute for Basic and Continuing Education of Health Workers: National Cancer Program. [Egészségügyi Szakképzô és Továbbképzö Intézet: Nemzeti Rákellenes Program.] Budapest, 2006. [Hungarian]

[11] Kovács, A., Döbrössy, L., Budai, A., et al.: Cervical screening in Hungary: why does the "English model" work but the "Hungarian model" does not? Eur. J. Gynaecol. Oncol., 2008, 29(1), 5-9.

[12] Pakai, A., Dér, A., Kriszbacher, I., et al.: Why don't Hungarian women take part in organized cervical screening? New Medicine, 2010, 1(14), S25-S28.

[13] Molnár, K., Kovács, A., Fuchs, N., et al.: The organised cervix cancer screening program carried out by district nurses in the public health program. [A védőnői cervix (méhnyak) szürés illeszkedése a népegészségügyi programba.] Egészség-akadémia, 2011, 2(2), 116-125. [Hungarian]

[14] Fehér, E.: 3 years of cervical cancer screening program carried out by health visitors. [A Védőnői Méhnyakszűrő Programok 3 éve.] Védőnő, 2012, 22(2), 5-9. [Hungarian]

[15] 49/2004. (V. 21.) Decree of Ministry of Health, Social and Family Affairs about provision of regional health visitors. [49/2004. (V. 21.) ESzCsM rendelet a területi védőnői ellátásról.] Available from: https://net.jogtar.hu/jr/gen/hjegy_doc. cgi? docid = a0400049. esc [accessed: November 6, 2015]. [Hungarian]

[16] 28/2013. (IV. 5.) Decree of Ministry of Humán Resources about provision of regional health visitors (Modification of the MHSFA decree). [28/2013. (IV. 5.) EMMI rendelet a területi védőnői ellátásról szóló 49/2004. (V. 21.) ESzCsM rendelet módosításáról.] Hatályos: 2013. 04. 20. - 2013. 05. 02. Available from: http://www.hbcs.hu/uploads/jogszabaly/1509/ fajlok/28_2013_emmir.pdf [accessed: November 6, 2015]. [Hungarian]

[17] Döbrössy, L., Kovács, A., Budai, A., et al.: Education and training of health visitors to undertake cervical screening. J. Nurs. Educ. Pract., 2015, 5(3), 28-32.

[18] Döbrôssy, L.: The health visitors' tasks in organised cervical cancer screening program. [A védőnők feladatai a népegészségügyi méhnyakszúrésben.] Védőnő, 2012, 22(2), 3-4. [Hungarian] 
[19] Döbrössy, L., Kovács, A., Budai, A., et al.: Screening for cervical cancer in Hungary: New role for health visitors. Clin. Nurs. Stud., 2013, 1(3), 32-38.

[20] Döbrössy, L., Cornides, Á., Kovács, A., et al.: Implementation status of cervical screening in Europe. [A rákellenes méhnyakszürés helyzete Európában.] Orv. Hetil., 2014, 155(50), 1975-1988. [Hungarian]

[21] Anttila, A., Ronco, G., Working Group on the Registration and Monitoring of Cervical Cancer Screening Programmes in the European Union; within the European Network for Information on Cancer (EUNICE): Description of the national situation of cervical cancer screening in the member states of the European Union. Eur. J. Cancer, 2009, 45(15), 2685-2708.

[22] Bruni, L., Barrionuevo-Rosas, L., Albero, G., et al.: ICO Information Centre on HPV and Cancer (HPV Information Centre). Human Papillomavirus and Related Diseases in Finland. Summary Report, 15 December 2016.

[23] Anttila, A., Nieminen, P.: Cervical cancer screening programme in Finland. Eur. J. Cancer, 2000, 36(17), 2209-2214.

[24] Bruni, L., Barrionuevo-Rosas, L., Albero, G., et al.: ICO Information Centre on HPV and Cancer (HPV Information Centre). Human papillomavirus and related diseases in Sweden. Summary Report, 2016.

[25] Dillner, J.: Cervical cancer screening in Sweden. Eur. J. Cancer, 2000, 36(17), 2255-2259.

[26] Comber, H., Gavin, A.: Recent trends in cervical cancer mortality in Britain and Ireland: the case for population-based cervical cancer screening. Br. J. Cancer, 2004, 91(11), 1902-1904.

[27] Veerus, P., Arbyn, M., Amati, C., et al.: Impact of implementing a nationwide cervical cancer screening program on female population coverage by Pap-tests in Estonia. Tumori, 2010, 96(4), 524-528.

[28] Bruni, L., Barrionuevo-Rosas, L., Albero, G., et al.: ICO Information Centre on HPV and Cancer (HPV Information Centre). Human papillomavirus and related diseases in Ireland. Summary Report, 2016

[29] van Ballegooijen, M., Hermens, R.: Cervical cancer screening in The Netherlands. Eur. J. Cancer, 2000, 36(17), 2244-2246.

[30] Riza, E., Kyriakogianni-Psaropoulou, P., Koumantakis, E., et al.: Cervical cancer screening in Greece. Eur. J. Cancer, 2000, 36(17), 2227-2232.

[31] Fernández Calvo, M. T., Hernández Rubio, A., Rosell Aguilar, I.: Cervical cancer screening in Spain. Eur. J. Cancer, 2000, 36(17), 2250-2254

[32] Januszek-Michalecka, L., Nowak-Markwitz, E., Banach, P., et al.: Effectiveness of the National Population-Based Cervical Cancer Screening Programme in Poland - Outcomes, problems and possible solutions 7 years after implementation. Ann. Agric. Environ. Med., 2013, 20(4), 859-864.

[33] Boncz, I., Sebestyén, A., Döbrössy, L., et al.: The coverage of cervical screening in Hungary. [A méhnyakszűrés részvételi mutatói Magyarországon.] Orv. Hetil., 2007, 148(46), 2177-2182. [Hungarian]

[34] Vajda, R., Karamánné Pakai, A., Éliás, Zs., et al.: Analysis of the knowledge on cervical cancer and attendance indicators of cervical screening. [A méhnyakrákkal kapcsolatos ismeretek és szúrővizsgálaton való részvételi mutatók vizsgálata.] Lege Artis Med., 2014, 24(3), 118-125. [Hungarian]

[35] Vajda, R., Molnár, K., Fuchs, N., et al.: Knowledge of human papillomavirus and cervical cancer topic. [Ismeretek a humán papillomavírus és a méhnyakrák témakörében.] Ápolásügy, 2012, 26(2), 15-18. [Hungarian]
[36] Vajda, R., Kálmán, D., Pakai, A., et al.: Knowledge of human papillomavirus among university students in Hungary. Value Health, 2014, 17(7), A648.

[37] Árváné Egri, Cs., Fehér, E., Szabó, M.: Experiences of health visitors performing cervical cancer screening about the participation in screening of the personally invited women. [Védőnói méhnyakrákszúrést végző védőnoók tapasztalata a szưrésre személyesen meghívott nők szứrésén való részvételével kapcsolatosan.] Védőnő, 2014, 24(5), 24-31. [Hungarian]

[38] Hanka, K.: My life in my hands! Why does not the organized cervical cancer screening work in Huhgary? [Kezemben az életem! Miért akadozik a szervezett méhnyakrák szúrés hazánkban?] Nővér, 2008, 21(4), 22-26. [Hungarian]

[39] Simek, Á., Budai, A., Kovács, A., et al.: With health visitors against cervical cancer. [Védőnőkkel a méhnyakrák ellen.] Családorvosi Fórum, 2010, 10(2), 41-46. [Hungarian]

[40] Döbrössy, L., Kovács, A., Budai, A., et al.: Gynecological screening or cervical screening? Conflicts between clinical and public health viewpoints. [Nőgyógyászati rákszűrés vagy méhnyakszűrés? Klinikai és népegészségügyi nézőpontok ütközése.] Orv. Hetil., 2012, 153(33), 1302-1313. [Hungarian]

[41] Langmár, Z., Németh, M., Kornya, L.: Cervical cancer screening in Hungary -epidemiological, historical and methodological aspects. [Méhnyakszűrés Magyarországon - epidemiológiai, történeti és módszertani vonatkozások.] Orv. Hetil., 2011, 152(51), 2063-2066. [Hungarian]

[42] Bösze, P.: The first vaccine against cancer: the human papillomavirus vaccine. [Az első védőoltás a rák ellen: az emberi papillomavírus elleni oltás.] Orv. Hetil., 2012, 154(16), 603-618. [Hungarian]

[43] Kásler, M., Ács, N., Bata, Z., et al.: The human papillomavirusrelated diseases, prevention possibilities and its public health importance. [A humán papillomavírus okozta megbetegedések, megelőzésük lehetőségei és ennek népegészségügyi előnyei.] Orv. Hetil., 2012, 153(Suppl. 4), 1-39. [Hungarian]

[44] Vanya, M., Jakó, M., Terhes, G., et al.: Low rate of oropharyngeal human papillomavirus infection among women with cervical lesion. Preliminary results from the South-Eastern Hungarian population. [Oropharyngealis humán papillomavírus ritka előfordulása cervicalis laesióval rendelkező nôkben. Elôzetes eredmények dél-magyarországi vizsgálat alapján] Orv. Hetil., 2016, 157(2), 70-73. [Hungarian]

[45] Hegyaljai, R., Paál, A., Langmár, Z., et al.: Women's knowledge about cervical cancer. [A nók ismeretei a méhnyakrákról.] Orv. Hetil., 2010, 151(8), 302-305. [Hungarian]

[46] Vajda, R., Kivés, Zs., Éliás, Zs., et al.: Attitude assessment of the human papilloma virus (HPV). [A humán papillómavírussal (HPV) kapcsolatos attitüdvizsgálat.] Magy. Nőorv. Lapja, 2014, $77(3), 18-25$. [Hungarian]

[47] Vajda, R., Miskolczi, A., Kives Horvathne, Z., et al.: Participation in cervical cancer screening and knowledge on human papillomavirus among women in Vác, Hungary. Value in Health, 2015, $18(3), \mathrm{A} 209$

[48] Ágoston, I., Sándor, J., Kárpáti, K., et al.: Economic considerations of HPV vaccination. Prev. Med., 2010, 50(1-2), 93.

(Vajda Réka,

Pécs, Mária u. 5-7., 7621

e-mail: reka.vajda@etk.pte.hu) 